\title{
PENGARUH NATTOKINASE TERHADAP DAYA KERJA Metformin HCI DALAM MENURUNKAN KADAR GLUKOSA DARAH PADA TIKUS PUTIH JANTAN (Rattus norvegicus) GALUR WISTAR
}

\section{THE EFFECT OF NATTOKINASE TO THE RESULT OF Metformin HCI IN DECREASING OF BLOOD GLUCOSE LEVEL IN WHITE MALE RATS (Rattus norvegicus) WISTAR STRAIN}

\author{
M. Sandila Okta, Vivi Sofia \\ Fakultas Farmasi Universitas Ahmad Dahlan \\ Jl. Prof Dr. Supomo, Yogyakarta. Telp. (0274) 379418 \\ Email :vi2_sophia@yahoo.com
}

\section{Abstrak}

Interaksi antara obat modern dan obat tradisional merupakan masalah yang perlu dicermati, tidak terkecuali dalam pengobatan diabetes mellitus. Nattokinase adalah produk nutraceutical yang dapat digunakan bersamaan dengan obat antidiabetika oral sehingga memungkinkan terjadinya interaksi. Penelitian ini bertujuan untuk mengetahui pengaruh Nattokinase terhadap daya kerja Metformin $\mathrm{HCl}$ dalam menurunkan kadar glukosa darah tikus putih jantan (Rattus norvegicus) galur Wistar. Penelitian ini menggunakan metode uji toleransi glukosa oral dengan pembebanan glukosa dosis $4,5 \mathrm{~g} / \mathrm{KgBB}$. Hewan uji yang digunakan yaitu tikus putih jantan galur Wistar umur 2-3 bulan dengan berat badan 150-200 gram, sebanyak 20 ekor yang dibagi menjadi 4 kelompok, masing-masing kelompok terdiri dari 5 ekor tikus. Kelompok I sebagai kelompok kontrol negatif diberi tween 80 - span 80, kelompok II sebagai kelompok kontrol positif diberi metformin HCl dosis $45 \mathrm{mg} / \mathrm{kg} \mathrm{BB}$, kelompok III diberi nattokinase dosis $300 \mathrm{mg} / \mathrm{kgBB}$, kelompok IV diberi nattokinase $300 \mathrm{mg} / \mathrm{kgBB}$ dan 1 jam kemudian diberi metformin HCl. 30 menit berikutnya semua kelompok perlakuan diberi glukosa. Saat perlakuan dianggap sebagai waktu ke-0. Pemberian glukosa dianggap sebagai waktu ke-30. Pengambilan darah melalui ekor pada menit ke- 0, 30, 60, 120, dan 180. Kadar glukosa darah diukur dengan alat Easy Touch. Efek 
penurunan kadar glukosa darah ditunjukkan dengan menghitung nilai LDDK0-180 (Luas Daerah Di bawah Kurva menit ke-0 sampai menit ke-180 dari grafik waktu vs kadar glukosa darah). Data yang didapat diuji statistik dengan Kruskal-Wallis dan Mann Whitney dengan taraf kepercayaan 95\%. Hasil penelitian menunjukan bahwa pemberian Metformin $\mathrm{HCl} 1$ jam setelah pemberian Nattokinase dapat menurunkan daya kerja Metformin $\mathrm{HCl}$ sebesar 52,22\%.

Kata kunci : Nattokinase, interaksi obat, diabetes mellitus.

\section{Abstract}

Interaction of modern drug and traditional drug is an issue that needs to be examined, not least in the treatment of diabetes mellitus. Nattokinase is a nutraceutical product that can be used in conjunction with antidiabetic oral drugs that allows the interaction. This study aims to determine the effect of Nattokinase against their power Metformin $\mathrm{HCl}$ in decreasing of blood glucose levels male white rats (Rattus norvegicus) Wistar. This study uses an oral glucose tolerance test with glucose loading dose of $4.5 \mathrm{~g} / \mathrm{kg}$. Animals test used were white male Wistar rats aged 2-3 months weighing 150-200 g, 20 rats were divided into 4 groups, each group consisted of 5 rats. Group I as a negative control group was given tween 80 - span 80, group II as a positive control group was given metformin $\mathrm{HCl}$ doses of $45 \mathrm{mg} / \mathrm{kg}$, group III was given Nattokinase dose $300 \mathrm{mg} / \mathrm{kgBB}$, group IV given nattokinase $300 \mathrm{mg} / \mathrm{kgBB} 1 \mathrm{hour}$ then were given metformin $\mathrm{HCl} .30$ minutes later all treatment of groups were given glucose. When treatment is considered as a time at- 0 . The given of glucose is considered as the time at-30. Blood sampling via the tail at 0,30, 60, 120, and 180. Blood glucose levels was measured with the Easy Touch. The effect of decreasing blood glucose levels indicated by the value of LDDK0-180 (Regional Area Under the Curve minute 0 to minute 180 of the graph time vs blood glucose levels). The data can be tested statistically by Kruskal-Wallis and Mann Whitney with a level of 95\%. The results showed that administration of Metformin $\mathrm{HCl}$ after 1 hour administration Nattokinase can be decreased 52.22\% of Metformin $\mathrm{HCl}$.

Key words : Nattokinase, drug interactions, diabetes mellitus 


\section{PENDAHULUAN}

Diabetes mellitus atau kencing manis adalah penyakit yang ditandai dengan kadar glukosa darah yang melebihi normal akibat tubuh kekurangan insulin. Penyakit ini disebabkan karena menurunnya hormon insulin yang diproduksi oleh kelenjar pankreas. Penurunan hormon ini mengakibatkan seluruh gula (glukosa) yang dikonsumsi tubuh tidak dapat diproses secara sempurna, sehingga kadar glukosa di dalam tubuh akan meningkat (Utami dkk, 2003).

Pada tahun 2011 International Diabetes Federation (IDF) memperkirakan bahwa sebanyak 183 juta orang tidak menyadari bahwa mereka terkena penyakit diabetes. IDF juga menyatakan bahwa jumlah orang yang hidup dengan diabetes diperkirakan akan meningkat dari 366 juta menjadi 552 milliar pada tahun 2030 jika tidak ada tindakan lebih lanjut. Hal ini setara dengan tiga kasus baru setiap sepuluh detik atau hampir sepuluh juta per tahun (Anonim, 2011).

Pengobatan penyakit diabetes dapat digunakan antara obat modern dengan obat modern atau obat modern dengan obat tradisional. Pada saat ini masyarakat cenderung menggunakan obat modern atau obat tradisional sebagai obat pendamping. Berdasarkan hal tersebut, salah satu obat pendamping dengan menggunakan Nattokinase. Nattokinase merupakan produk nutraceutical dengan kandungan enzim nattokinase yang memiliki efek khusus untuk melancarkan aliran darah dengan cara memecah fibrin (serat-serat bekuan
darah)(Sumi dkk, 1990). Nattokinase adalah enzim fibrinolitik kuat yang terkandung dalam natto, Natto adalah makanan fermentasi kedelai tradisional di Jepang yang sudah dikonsumsi selama lebih dari 1.000 tahun. Dalam organisme hidup, plasmin bekerja langsung pada fibrin yang menyebabkan fibrinolisis, tetapi telah ditemukan bahwa nattokinase tidak hanya secara langsung menyebabkan fibrinolisis tetapi juga memiliki efek yang kuat dalam mengaktifkan molekul pro-urokinase, sehingga menunjukkan bahwa nattokinase juga memiliki aktivitas fibrinolisis (Sumi dkk, 2009). Produk ini di masyarakat sering digunakan untuk mengatasi kesemutan dan gangren pada pasien diabetes mellitus yang berawal dari tidak lancarnya aliran darah akibat kadar glukosa darah yang tinggi. Salah satu obat antidiabetik oral yang sering digunakan adalah Metformin $\mathrm{HCl}$, terutama bagi penderita diabetes mellitus tipe 2 disertai kegemukan. Pada penderita diabetes mellitus yang disertai kegemukan dianjurkan untuk menggunakan Metformin $\mathrm{HCl}$, karena dapat menurunkan nafsu makan (Katzung, 2001).

Tujuan dari penelitian ini adalah untuk mengetahui apakah Nattokinase dapat menurunkan kadar glukosa darah pada tikus putih jantan galur Wistar dan untuk mengetahui apakah Nattokinase dapat berpengaruh terhadap daya kerja dari obat antidiabetes Metformin $\mathrm{HCl}$ pada tikus putih jantan galur Wistar, sehingga dapat diketahui waktu yang paling tepat untuk meminum kedua obat tersebut bila penggunaannya diberikan selang waktu 1 jam. 


\section{METODE PENELITIAN}

Alat

Alat yang digunakan pada penelitian ini yaitu kandang, timbangan hewan, spuit oral, timbangan gram analitik, mortir, stamfer, gelas beker, labu takar, pipet tetes, batang pengaduk, pisau, stop watch, Easy Touch dan strip.

\section{Bahan}

\section{Bahan Uji}

Bahan uji yang digunakan adalah D-Glukosa monohidrat, Nattokinase, Aquadest, dan Tween 80 - Span 80.

\section{Bahan Pembanding}

Bahan pembanding yang digunakan adalah Metformin $\mathrm{HCl}$ yang diperoleh dari Apotek K24 Jl. Kusumanegara No. 86, Yogyakarta.

\section{Hewan Uji}

Hewan uji yang digunakan adalah tikus putih jantan galur Wistar umur 2-3 bulan yang mempunyai berat $150-200$ gram, dari Universitas Islam Indonesia Yogyakarta.

\section{Jalannya Penelitian}

\section{Pengelompokan dan perlakukan hewan uji}

Penelitian ini menggunakan Uji Toleransi Glukosa Oral dengan cara memberikan pembebanan glukosa kepada hewan percobaan (Mayes, 1991). Hewan uji dibagi secara acak menjadi empat kelompok yang terdiri dari lima ekor tikus putih jantan galur Wistar.
Tikus dipuasakan terlebih dahulu 8-10 jam dengan tetap diberi minum ad libitum sebelum perlakukan. Kemudian tiap kelompok tikus diberi perlakuan sebagai berikut:

Kelompok I : sebagai kontrol negatif, diberi Tween 80 - Span 80. 30 menit kemudian diberi glukosa $4,5 \mathrm{~g} / \mathrm{kg}$ BB.

Kelompok II : sebagai kontrol positif, diberi Metformin $\mathrm{HCl}$ $45 \mathrm{mg} / \mathrm{kg}$ BB. 30 menit kemudian diberi glukosa $4,5 \mathrm{~g} / \mathrm{kg} \mathrm{BB}$.

Kelompok III : diberi Nattokinase 300 $\mathrm{mg} / \mathrm{kgBB}, 30$ menit kemudian diberi glukosa $4,5 \mathrm{~g} / \mathrm{kg} \mathrm{BB}$.

Kelompok IV : diberi Nattokinase 300 $\mathrm{mg} / \mathrm{kgBB}, \quad 1 \quad$ jam kemudian diberi Metformin $\mathrm{HCl}$. 30 menit kemudian diberi glukosa 4,5 g/kg BB.

Setelah hewan uji diberikan glukosa maka pengambilan darah dilakukan pada menit ke 60, 120, 180, sehingga pengambilan darah setiap hewan uji dari ekor secara keseluruhan dilakukan pada menit ke 0,30,60, 120, 180. Setelah itu diukur kadar glukosanya dengan menggunakan alat Easy Touch.

\section{Analisis Data}

Data yang berupa kadar glukosa darah dianalisis dengan $\mathrm{LDDK}_{0-\mathrm{n}}$ dengan rumus trapesium untuk masing-masing perlakuanya itu : 


$$
\operatorname{LDDK}_{0-\mathrm{n}}=\left[\frac{\mathrm{t}_{1}-\mathrm{t}_{0}}{2} \mathrm{x}\left(\mathrm{C}_{0}+\mathrm{C}_{1}\right)\right]+\left[\frac{\mathrm{t}_{2}-\mathrm{t}_{1}}{2} \mathrm{x}\left(\mathrm{C}_{1}+\mathrm{C}_{2}\right)\right]+\ldots . .+\left[\frac{\mathrm{t}_{\mathrm{n}}-\mathrm{t}_{\mathrm{n}-1}}{2} \mathrm{x}\left(\mathrm{C}_{\mathrm{n}}+\mathrm{C}_{\mathrm{n}-1}\right)\right]
$$

\section{Keterangan :}

$$
\begin{array}{ll}
\text { LDDK } & \text { : Luas Daerah di bawah Kurva } \\
\mathrm{t} & \text { : waktu (menit) } \\
\mathrm{C} & : \text { kadar glukosa darah }(\mathrm{mg} / \mathrm{ml})
\end{array}
$$

Data diuji dengan Kruskal-Wallis dan Mann-Whitney dengan taraf kepercayaan $95 \%$.

Untuk mengetahui kemampuan sediaan dalam menurunkan kadar glukosa darah, maka dihitung persentase penurunan kadar glukosa darah dengan rumus sebagai berikut:

Persentase penurunan kadar glukosa darah $=$
B : Persentase penurunan kadar glukosa darah kelompok pemberian Nattokinase dan Metformin $\mathrm{HCl}$.

\section{HASIL DAN PEMBAHASAN}

Penelitian ini menggunakan tikus putih jantan galur Wistar dengan metode uji toleransi glukosa oral. Pembebanan glukosa akan menyebabkan peningkatan kadar glukosa darah secara cepat dan dapat diturunkan secara cepat pula oleh zat-zat yang berefek antihiperglikemik. Darah diambil dari ekor pada menit ke 0, 30, 60, 120, dan 180 (Widman, 1989). Pada menit - menit tersebut langsung dihitung kadar glukosa darahnya dengan menggunakan alat Blood Glucose Test Easy Touch

$$
\frac{\text { (LDDK }_{0-180} \text { kontrol negatif)-(LDDK }}{0-180 \text { kontrol positif / perlakuan }) \times 100 \%}
$$

Sedangkan untuk mengetahui penurunan daya kerja Metformin $\mathrm{HCl}$ oleh Nattokinase maka dihitung persentase penurunan daya kerja dengan rumus sebagai berikut :

Penurunan daya kerja $=$ A-B

\section{Keterangan :}

A : Persentase penurunan kadar glukosa darah kontrol positif Metformin $\mathrm{HCl}$.
Purata perubahan kadar glukosa darah tikus pada menit-menit tertentu untuk semua kelompok perlakuan dapat dilihat pada Tabel I 
Tabel I : Perubahan kadar glukosa darah tikus pada menit ke-0 sampai menit ke- 180 kelompok I, II, III, dan IV

\begin{tabular}{|c|c|c|c|c|c|}
\hline \multirow{2}{*}{ kelompok } & \multicolumn{5}{|c|}{ Purata perubahan kadar glukosa darah (rata-rata \pm SD) menit ke-(mg/dl) } \\
\cline { 2 - 6 } & $\mathbf{0}$ & $\mathbf{3 0}$ & $\mathbf{6 0}$ & $\mathbf{1 2 0}$ & $\mathbf{1 8 0}$ \\
\hline I & 0 & $50.4 \pm 15.78924$ & $81.4 \pm 19.57805$ & $37.4 \pm 31.71435$ & $16.6 \pm 10.78425$ \\
\hline II & 0 & $10.2 \pm 8.288546$ & $17.6 \pm 10.66771$ & $16.4 \pm 10.62073$ & $14.6 \pm 4.827007$ \\
\hline III & 0 & $22.6 \pm 6.730527$ & $37.4 \pm 7.197222$ & $26.8 \pm 8.757854$ & $11.2 \pm 6.942622$ \\
\hline IV & 0 & $24 \pm 10.27132$ & $44.8 \pm 10.05982$ & $53 \pm 5.147815$ & $24.6 \pm 15.24139$ \\
\hline
\end{tabular}

Kelompok I : sebagai kontrol negatif, diberi Tween 80 Span 80.30 menit kemudian diberi glukosa $4,5 \mathrm{~g} / \mathrm{kg} \mathrm{BB}$.

Kelompok II : sebagai kontrol positif, diberi Metformin $\mathrm{HCl}$ $45 \mathrm{mg} / \mathrm{kg} \mathrm{BB}$. 30 menit kemudian diberi

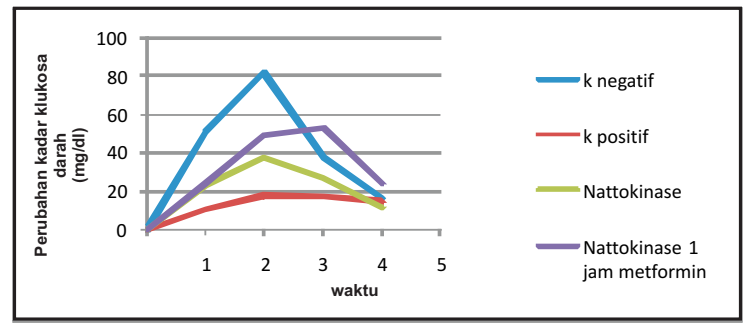
glukosa $\quad 4,5$

Gambar 1. Kurva purata perubahan kadar glukosa darah terhadap waktu untuk semua kelompok

$\mathrm{g} / \mathrm{kg} \mathrm{BB}$.

Kelompok III : diberi Nattokinase 300 $\mathrm{mg} / \mathrm{kgBB}, \quad 30$ menit kemudian diberi glukosa $4,5 \mathrm{~g} / \mathrm{kg} \mathrm{BB}$.

Kelompok IV : diberi Nattokinase 300 $\mathrm{mg} / \mathrm{kgBB}, \quad 1$ jam kemudian diberi metformin $\mathrm{HCl} .30$ menit kemudian diberi glukosa $4,5 \mathrm{~g} / \mathrm{kg} \mathrm{BB}$.

Dari purata kadar pada menitmenit tertentu untuk semua kelompok perlakuan dapat dibuat kurva hubungan antara kadar glukosa darah terhadap waktu untuk semua kelompok perlakuan dapat dilihat pada gambar 1 .
Untuk membandingkan efek antihiperglikemik antara kelompok satu dengan yang lain maka dihitung perubahan kadar glukosa darah dari tiap kelompok perlakuan, kemudian dihitung luas daerah dibawah kurvanya pada menit ke-0 sampai menit ke180 $\left(\mathrm{LDDK}_{0-180}\right)$. Perbandingan $\mathrm{LDDK}_{0-180}$ antar kelompok perlakuan dapat dilihat pada gambar 2 .

Perubahan pada kadar glukosa darah yang ada dalam darah selama 180 menit karena pengaruh masingmasing perlakuan dalam setiap kelompok. Nilai LDDK $_{0-180}$ berbanding terbalik dengan efek antihiperglikemik dari suatu sediaan. Semakin kecil nilai LDDK maka 


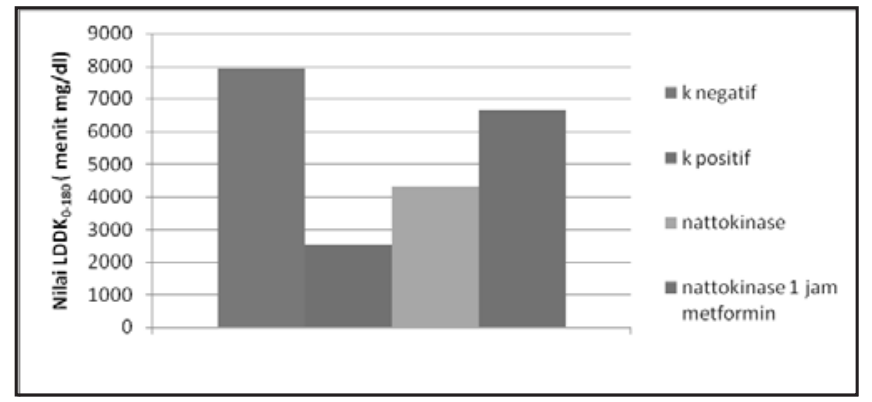

Gambar 2. Kurva perbandingan nilai $\mathrm{LDDK}_{0-180}$ tiap kelompok perlakuan nilai LDDK $_{0-180}$ setiap kelompok perlakuan menunjukkan jumlah

semakin besar daya anti-hiperglikemiknya.

\section{Pengaruh Nattokinase Terhadap Daya Kerja Metformin HCl Dalam Menurunkan Kadar Glukosa Darah}

Berdasarkan nilai LDDK $_{0-180}$ dapat dikatakan bahwa dengan pemberian metformin $\mathrm{HCl} 1$ jam setelah pemberian nattokinase menyebabkan penurunan daya kerja dari metformin $\mathrm{HCl}$. Selain itu kelompok nattokinase 1 jam kemudian diberi metformin $\mathrm{HCl}$ memiliki efek antihiperglikemik karena memiliki LDDK $_{0-180} 6654$ menit mg/dl

dan lebih kecil dari pada kontrol negatif tween 80 - span 80 yaitu 7917 menit $\mathrm{mg} / \mathrm{dl}$.

\section{Hasil Uji Statistik Data LDDK $_{0-180}$}

Hasil uji statistik LSD LDDK $_{0-180}$ tiap pasangan kelompok perlakuan dapat dilihat pada Tabel II.

Tabel II. Hasil uji statistik LSD nilai LDDK $_{0-180}$ tiap pasangan kelompok perlakuan.

\begin{tabular}{|l|c|l|c|}
\hline $\begin{array}{c}\text { Pasangan kelompok } \\
\text { Perlakuan }\end{array}$ & P.(Asymp.sig) & \multicolumn{1}{|c|}{ Hasil uji antar pasangan } & Keterangan \\
\hline Kelompok I-II & $\mathrm{P}<0.05$ & Berbeda bermakna & $\mathrm{I} \neq$ II \\
\hline Kelompok I-III & $\mathrm{P}<0.05$ & Berbeda bermakna & $\mathrm{I} \neq$ III \\
\hline Kelompok I-IV & $\mathrm{P}>0.05$ & Berbeda tidak bermakna & $\mathrm{I}=\mathrm{IV}$ \\
\hline Kelompok II-III & $\mathrm{P}<0.05$ & Berbeda bermakna & $\mathrm{II} \neq \mathrm{III}$ \\
\hline Kelompok II-IV & $\mathrm{P}<0.05$ & Berbeda bermakna & $\mathrm{II} \neq \mathrm{IV}$ \\
\hline Kelompok III-IV & $\mathrm{P}<0.05$ & Berbeda bermakna & $\mathrm{III} \neq \mathrm{IV}$ \\
\hline
\end{tabular}


Tabel III : Hasil perhitungan persentase penurunan kadar glukosa darah pada kelompok I, II, III, dan IV

\begin{tabular}{|c|c|c|c|c|}
\hline Kelompok & $\mathrm{LDDK} \pm \mathrm{SD}$ & $\begin{array}{c}\text { \% Penurunan } \\
\text { kadar Glukosa } \\
\text { darah }\end{array}$ & $\begin{array}{l}\text { \% Penurunan } \\
\text { daya kerja } \\
\text { Metformin } \mathrm{HCl}\end{array}$ & $\begin{array}{l}\% \text { Peningkatan } \\
\text { daya kerja } \\
\text { Metformin HC1 }\end{array}$ \\
\hline I & $7917 \pm 3581,078$ & $0 \%$ & - & - \\
\hline II & $2520 \pm 1510,758$ & $68,17 \%$ & - & - \\
\hline III & $4305 \pm 1259,541$ & $45,62 \%$ & - & - \\
\hline IV & $6654 \pm 1526,942$ & $15,95 \%$ & $52,22 \%$ & - \\
\hline
\end{tabular}

Hasil Perhitungan Persentase Penurunan Kadar Glukosa Darah

Keterangan :

Kelompok I : sebagai kontrol negatif, diberi Tween 80 - Span 80. 30 menit kemudian diberi glukosa $4,5 \mathrm{~g} / \mathrm{kg}$ BB.

Kelompok II : sebagai kontrol positif, diberi Metformin $\mathrm{HCl}$ $45 \mathrm{mg} / \mathrm{kg}$ BB. 30 menit kemudian diberi glukosa $4,5 \mathrm{~g} / \mathrm{kg} \mathrm{BB}$.

Kelompok III : diberi Nattokinase 300 $\mathrm{mg} / \mathrm{kgBB}, \quad 30$ menit kemudian diberi glukosa $4,5 \mathrm{~g} / \mathrm{kg}$ BB.

Kelompok IV: diberi Nattokinase 300 $\mathrm{mg} / \mathrm{kgBB}, \quad 1$ jam kemudian diberi metformin $\mathrm{HCl} .30$ menit kemudian diberi glukosa 4,5 g/kg BB.

Dari Tabel III dapat dilihat bahwa semua kelompok perlakuan mempunyai kemampuan menurunkan kadar glukosa darah tikus jantan kecuali kelompok I.
Kelompok III yang merupakan kontrol nattokinase dosis $300 \mathrm{mg} / \mathrm{kgBB}$ mempunyai persentase penurunan kadar glukosa darah sebesar $45,62 \%$ artinya nattokinase dosis $300 \mathrm{mg} / \mathrm{kgBB}$ mempunyai daya antihiperglikemik walaupun tidak sebesar Metformin $\mathrm{HCl}$ yaitu $68,17 \%$. Hal ini kemungkinan pada keadaan hiperglikemia terjadi peningkatan viskositas darah yang dapat mencetuskan terjadinya perubahan dalam faal hemostasis. Enzim nattokinase memiliki efek khusus untuk melancarkan aliran darah dengan cara memecah fibrin (serat-serat bekuan darah). Fibrin tersebut akan merangsang aktivasi plasminogen menjadi plasmin oleh aktivator plasminogen seperti tissue plasminogen aktivators (t-PA). Plasmin yang terbentuk akan memecah fibrinogen dan fibrin menjadi fibrin degradation product (FDP) (Pais, 2006), sehingga aliran darah menjadi lancar dan menyebabkan glukosa dapat terdistribusi secara baik ke bagian tubuh lain, sehingga terjadi penurunan kadar glukosa darah.

Penurunan kadar glukosa darah pada kelompok IV jauh lebih kecil 
dibandingkan penurunan kadar glukosa darah oleh Metformin $\mathrm{HCl}$ yaitu 68,17\%. Hal ini menunjukkan bahwa daya kerja Metformin $\mathrm{HCl}$ menurun dengan pemberian Nattokinase 1 jam kemudian diberikan Metformin $\mathrm{HCl}$. Hal ini dimungkinkan terjadi interaksi obat tetapi belum dapat dipastikan interaksi apa yang terjadi.

Penurunan daya kerja dari metformin $\mathrm{HCl}$ ini sangat merugikan pasien bagi yang melakukan terapi dengan menggunakan nattokinase. Belum diketahui secara pasti interaksi yang terjadi, interaksi yang merugikan ini dimungkinkan terjadi karena adanya interaksi farmasetis yaitu pada saat pencampuran obat biasanya berakibat inaktivasi obat, interaksi farmakokinetik yaitu bila salah satu obat mempengaruhi absorbsi, distribusi, metabolisme, atau ekskresi obat kedua dengan mengukur kadar obat di dalam darah. Pada penelitian ini yang diamati adalah efek penurunan kadar glukosa darah jika pemberian nattokinase 1 jam kemudian diberikan metformin $\mathrm{HCl}$. Jadi interaksi yang mungkin terjadi adalah interaksi farmakodinamik, dimana peningkatan atau penurunan efek suatu obat karena pengaruh obat/senyawa lain (Harkness, 1989).

Dari hasil dan pembahasan di atas menunjukkan bahwa nattokinase dapat menurunkan kadar glukosa darah yang secara statistik penurunannya tidak bermakna sehingga penderita hiperglikemik dapat mengkonsumsi nattokinase. Tetapi mengkonsumsi nattokinase tersebut tidak boleh dengan selang waktu 1 jam sebelum pemberian metformin $\mathrm{HCl}$ karena dapat menurun- kan daya kerja dari metformin $\mathrm{HCl}$ itu sendiri.

\section{KESIMPULAN}

Pemberian nattokinase dapat menurunkan kadar glukosa darah sebesar $45,62 \%$ dan pemberian nattokinase 1 jam kemudian diberikan metformin $\mathrm{HCl}$, dapat menurunkan daya kerja metformin $\mathrm{HCl}$ sebesar 52,22\%.

\section{DAFTAR PUSTAKA}

Anonim, 2011, International Diabetic Federation (IDF), Available on: (http://www.idf.org/media-event/ press-releases/2011/diabetes-atlas -5th-edition), diakses tanggal 25 Juli 2011.

Harknes, 1989, Interaksi Obat, diterjemahkan oleh Goeswin Agoes dan Mathilda B, Widianto, Penerbit ITB, Bandung.

Katzung, Bertram, 2001, Basic \& Clinical Pharmacology, Eighth Edition, Salemba Medika, Jakarta

Mayes,1995, Glikoneogenesis dan Pengendalian Kadar Glikosa Darah, dalam Murray, R.K., Granner, D.K., Mayes, P.A., dan Rodwell, V.M., (Eds) Biokimia Harper, Diterjemahkan oleh Andry Hartono, edisi XXII, 227, Penerbit Buku Kedokteran EGC, Jakarta.

Pais, Alexy, Holsworth, Meiselman, 2006, Effect of nattokinase, a pro-fibrinolytic enzyme, on red blood cell aggregation and whole blood viscosity. Clin Hemorheol Microcirc, 35(1-2), 139-42. 
Sumi, Hamada, Nakanishi, Hiratani, 1990, Enhancemet of the fibrinolytic activity in plasma by oral administration of nattokinase, Acta Haematol ; 84(3) :139-43.

Sumi,Ikeda, Ohsugi, 2009, Increasing the Production of Nattokinase and Vitamin $\mathrm{K} 2$ in Natto with Dipicolinic Acid, Department of Physiological Chemistry, Kurashiki University of Science and the Arts, Kurashiki 712-8505, Japan.
Utami, Prapti dan Tim Lentera, 2003, Tanaman Obat untuk Mengatasi Diabetes Mellitus, Agromedia Pustaka, Tangerang. Hal 12-16

Widmann,1989, Tinjauan Klinis atas Hasil Pemeriksaan Laboratorium, Edisi kesembilan, 468-469, diterjemahkan oleh Siti Boedina Kresno, R. Ganda- soebrata, dan, J. Latu, Penerbit Buku Kedokteran EGC, Jakarta. 